\title{
College Student Party Members Actively Participate in the Public Opinion Guidance Mechanism of We-Media
}

\author{
Yan Wu*, Yujiao Song, Yanying Zhou, Fang Wang, Mengshan Li \\ Gannan Normal University, Ganzhou, China \\ Email: ${ }^{\star j c i \_w u @ 163 . c o m ~}$
}

How to cite this paper: Wu, Y., Song, Y.J., Zhou, Y.Y., Wang, F. and Li, M.S. (2019) College Student Party Members Actively Participate in the Public Opinion Guidance Mechanism of We-Media. Open Journal of Social Sciences, 7, 403-410.

https://doi.org/10.4236/jss.2019.712031

Received: December 9, 2019

Accepted: December 23, 2019

Published: December 26, 2019

Copyright $\odot 2019$ by author(s) and Scientific Research Publishing Inc. This work is licensed under the Creative Commons Attribution International License (CC BY 4.0).

http://creativecommons.org/licenses/by/4.0/

\begin{abstract}
In the era of we-media, due to the characteristics of the objects of guidance of online public opinion in colleges and universities, the diversity of guidance methods and the need of cultivating party members' consciousness, it is decided that to do a good job in the guidance of online public opinion in colleges and universities, student party members must play an important role. Student party members are an important force to maintain the safety of ideology and an important example to guide students' speech in the guidance of online public opinion. Therefore, to strengthen the guidance of online public opinion of student party members and build a team of online public opinion of all student party members, we must strengthen the training and improve the guidance ability of student party members to carry out various forms of educational activities, establish the guiding mechanism of joint management, give full play to the advanced exemplary role of student party members and strengthen the guidance effect of online public opinions.
\end{abstract}

\section{Keywords}

We Media, Student Party Member, Online Public Opinion, Guidance Mechanism

\section{Introduction}

The Internet platform has become a new public opinion field, where everyone is a speaker and everyone can express his or her own opinion at any time. At this time, if the guidance is weak or improper, maybe a hearsay ferment, catalysis, rapid warming will form a "butterfly effect". It is easy for local issues to expand into overall issues, for general issues to evolve into political issues, and for individual extreme remarks to spread into irrational social emotions, directly affect- 
ing social stability. Therefore, strengthening the guidance of network public opinion has become an important and urgent task. Chinese scholars' approaches to public opinion guidance mainly include the following aspects. Second, some scholars proposed to improve the ability of new media and social groups to guide public opinion through agenda setting. Third, some scholars proposed that we media release information to guide public opinion. Fourth, some scholars put forward the integrated use of public opinion guidance and public opinion supervision methods to guide public opinion. Fifth, some scholars proposed to guide public opinion through the construction of socialist core value system. Foreign scholars do not limit their research on methods and approaches of public opinion guidance to the field of communication, but adopt different methods in combination with different fields and make them connect and cooperate with each other, so as to maximize the role and effect of public opinion guidance. Specifically, it is mainly reflected in the following aspects: First, to guide public opinion through various forms of public opinion survey; second, public relations personnel, opinion leaders, think tanks and so on to obtain public opinion and influence public opinion. third, to guide public opinion through ideological propaganda and indoctrination [1] [2].

The above methods and approaches lay particular stress on the methods and approaches of network public opinion guidance from the macro level, but for the college students, a special group, no specific measures are proposed from the grass-roots organizations. The majority of college students become a new force in the dissemination and acceptance of network public opinion. Various network behaviors constitute an important part of college students' life, forming a special public opinion field in the campus field with the characteristics of college students. As a result, a line of ideological and political education workers single alone has been impossible to complete the network public opinion supervision task, how to use network position at the grassroots level to carry out the ideological and political education, with correct, positive and healthy culture occupy the network position, at the same time to prevent some people use network transmission error, low-level and harmful of ideas and information, to guide the media public opinion of the campus which is a urgent task. Student party members are the vanguard among college students and are widely distributed in various grassroots organizations. They live with ordinary students all the time, often communicate with students in the dormitory, pay attention to campus "we media", and can make an immediate response and build a direct bridge to understand the public opinions of students. Therefore, this paper studies the active participation of student party members in the guidance of public opinion of online we-media and the dissemination of positive energy, which is very meaningful and valuable [3] [4].

\section{The Necessity for Student Party Members to Participate in the Guidance of Online Public Opinion}

\subsection{University Student Party Member's Characteristic Demand}

The characteristics of college student party members require college students as 
participants in college network public opinion have the following characteristics. One is younger. According to statistics, the basic filial piety of college students is between 17 and 22 years old. Therefore, college students are the relatively young group among Internet users, who are very easy to accept the public opinion influence of other Internet users with the same education level and age. The second is conformity. College students, with limited experience, are easily influenced by the public opinion environment when they enter the society for the first time. They do not have a high recognition of false public opinion, and may even be used as a facilitator of false public opinion, eventually leading to a crisis of public opinion on the Internet and affecting social stability. Therefore, these characteristics determine that the guidance of online public opinion in colleges and universities needs to give full play to the role of party members of students with similar age and psychology, spread mainstream ideas and enhance positive energy [5] [6].

\subsection{Diversity of Guidance Needs}

Guide the way the diversity of the decision of oneness and traditional media transmission way is different, since the media information dissemination is the feature of complex network transmission, each individual can be either communicators, also can be the recipient, and the identity of communicators and recipients are overlapping, change, can immediately after the end of the dissemination of public opinion into the next public opinion of the recipient, as a result, the traditional media can spread to accept the single transmission into the combination of spread and accept diversity network transmission. The diversity of the guide way determines the diversity of the college students' network public opinion guide way, namely, the related functional sections in high schools, counselors, teachers can solve the problem of lead from a single way, and should, cultivating student party members in the guide team, give full play to the important role of student party members, can achieve good effect [7].

\subsection{The Cultivation of Party Member Consciousness Needs}

The party member consciousness is the party member individual to the party nature, the objective, the mission and so on consciousness identification. Student party member joins the party in the organization while, must continue to accept the party organization's inspection and the training, joins the party in the thought, plays the vanguard exemplary role in the student. Therefore, establishing a guidance mechanism for student party members to participate in online public opinion can not only improve the efficiency of online public opinion guidance and the effect of control, but also temper the party spirit cultivation of student party members, improve their awareness of party membership, stimulate their enthusiasm, initiative and creativity, and strengthen the awareness of party members by combining knowledge with action. Therefore, it is very necessary to cultivate the consciousness of party members from students' participation in on- 
line public opinions [8] [9] [10].

\section{The Role of Student Party Members in the Guidance of Online Public Opinion}

\subsection{The Guiding Force of Student Party Members}

Ideal faith firmness, is an important force in maintaining ideology security in terms of party members development process now, should pass to submit application form to join the party, to join the party activists training, writing thought report, investigation and development program, the probationary party member and a year's time, therefore, the development process is relatively strict. In terms of volume, the student party members of college students is less than $10 \%$, therefore, although now the student party members such as insufficient theory accomplishment is not enough, the party spirit accomplishment, to join the party motivation not pure and other problems, but they generally are the excellent student firm ideal faith groups in college students, has a political stance, the academic record outstanding, consciously abide by the laws and regulations, etc, can take the lead in the students' ideological and political education to study the party's theory, the party constitution, the party and the party's major policies, laws and regulations, the rules the school rules, model law-abiding, carry forward the socialist core values, spread the positive energy, etc. The important role of. It is an important force in safeguarding the ideological security of the party and the country [11] [12].

\subsection{Student Party Members Are Guided by Example}

Self development guides the student to speech is an important model in the student party members, there are quite a part of the student cadre, has the characteristics of excellent, ability strong, is among the students, not only good performance, and ability of organization, coordination ability, good communication ability, is responsible for the student management, class management, part of the group learning activities work, have certain prestige and popularity among the students, play an exemplary role in study and life, therefore, if give full play to its role in public opinion guide can be an example to guide the student to the important speech [13] [14].

\section{Student Party Member Network Public Opinion Guidance Strategy}

\subsection{Improve the Online Public Opinion Team of Student Party Members}

It is important to improve the guidance ability of student party members by training their comprehensive ability. It is necessary to strengthen the training of student party members through various forms and channels, make every effort to improve the ideological and moral standards, and the political literacy of student party members, and strive to improve their ability to capture information, 
analyze and judge, respond to emergencies, and scientific feedback, and build powerful public opinion team of student party members. It is important to deepen the education and training of party members and form a strong ideological cornerstone. According to the requirements of the student party branch standardization, the theoretical study and practical study, classroom learning, and self-learning after class must be combined [15] [16] [17].

\subsection{We Will Carry out Various Forms of Educational Activities}

It is necessary to combine the characteristics of students' professions and enrich the form of education. Educational activities can be carried out in the following forms: First, party day activities, go deep into the masses, with fresh social practice to improve party spirit; second, reading activities recommend the party history and current political books, selection of outstanding essays, improve the ideological quality and moral cultivation of students; third, individual conversation, in-depth party member of students' study and life, to understand the students' ideological dynamics, learning, life, targeted to guide, deepen the understanding of the party's theory. Second, the guidance ability training should be strengthened, the quality of guidance ability should be improved. According to the requirements of online public opinion guidance, the training of student party members can be strengthened, and the strategies and methods of online public opinion guidance can be taught to everyone by professional lectures, online teaching, after-class discussion, case analysis, scene simulation, group discussion and other teaching forms. It is necessary to pay attention to the practicability and operability of the training content, focus on the process guided by online public opinion and the response to emergencies caused by online public opinion, and cultivate students' ability of detection and disposal [18] [19].

\subsection{Establish a Guiding Mechanism for Joint Management}

To set up a school network public opinion leadership group, secondary school to secretary and deputy secretary of the CPC at the grass roots level, mtcsol counselors into the network public opinion guide team, to develop student party members on duty system and network daily examination system, to establish head of school leaders, secondary school head for those responsible, instructor and the student party members is responsible for the work mechanism. Second, the network duty system, the network daily inspection system and public opinion information report and processing procedures should be improved. According to "who discovered, who reported, feedback, who is responsible for" work principle, requires that all the personnel on duty, the inspectors by browsing web sites, search engine, check emails, check the Weibo and WeChat, collect information about network public opinion, especially for some sensitive and could affect national security and social stability of network public opinion information, be sure to do it in accordance with the working procedures, submit the relevant leaders. Student party members should assist counselors to guide 
public opinion on the Internet. In the case of online public opinions, it is necessary to timely contact the counselors, assist the counselors to find the source of online public opinions, and verify the authenticity of online public opinions. For false information that is not true, rumors can be refuted as peers, play the peer effect, insist on speaking with facts, and firmly grasp the initiative of online public opinions. Therefore, it is very necessary to integrate student party members into the network public opinion management mechanism [20].

\subsection{Give Full Play to the Advanced Exemplary Role of Student Party Members}

The first is to play the role of "opinion leaders", adhere to the positive voice, to seize the position of public opinion. Student party members should strive to be the "opinion leaders" of online public opinion and make their voices heard in time. We should train student party members to become BBS moderators, commentators, etc., through the network hot events, especially hot campus news comments, preempt others, the socialist values into the comments and reasoning. Student party members have a better understanding of the concerns of the student group, so the hot topics of the comments are more likely to attract their attention. Moreover, they can also play their advantages of being close to the age of the recipient, have certain common language, and can also put themselves in the shoes of other students to gain their trust. Second, give full play to the role of "opinion clarification", grasp the effectiveness of effective response to false information. Since the media age, because everyone can for publishing information, publishing information, time also appeared diversity, the purpose of public opinion will appear some information distortion in colleges and universities, the phenomenon of indiscreet remarks, more serious is that, under the influence of the students, the elder brothers friendship and so on, there is no reason to forward the behavior of evolution of network public opinion even mass incidents. In case of negative online public opinions, the party members of the students should give timely feedback according to the processing process, and the counselors should report to the leaders in charge of the college to optimize the working mechanism of quick response to online public opinions. For the distorted online speech, the student party members should timely clarify the facts in accordance with the requirements of the counselor, adhere to the principle of "reason, basis, advantage and restraint", refute the malicious attacks of people with ulterior motives, so as to minimize the negative effects of public opinion [21] [22] [23].

\section{Acknowledgements}

The authors gratefully acknowledge the support from the Party Building Research Project of Jiangxi province (Grant Numbers: 400266).

\section{Conflicts of Interest}

The authors declare no conflicts of interest regarding the publication of this paper. 


\section{References}

[1] Kaufman, D.J., Murphy-Bollinger, J., Scott, J. and Hudson, K.L. (2009) Public Opinion about the Importance of Privacy in Biobank Research. American Journal of Human Genetics, 85, 643-654. https://doi.org/10.1016/j.ajhg.2009.10.002

[2] Cunningham, M.L., Regan, M.A., Horberry, T., Weeratunga, K. and Dixit, V. (2019) Public Opinion about Automated Vehicles in Australia: Results from a Large-Scale National Survey. Transportation Research Part A Policy and Practice, 129, 1-18. https://doi.org/10.1016/j.tra.2019.08.002

[3] Dutwin, D. (2019) Presidential Address: The Need for Public Opinion Research Advocacy. Public Opinion Quarterly, 83, 650-658. https://doi.org/10.1093/poq/nfz039

[4] Boyle, M.P. (2017) Personal Perceptions and Perceived Public Opinion about Stuttering in the United States: Implications for Anti-Stigma Campaigns. American Journal of Speech-Language Pathology, 26, 921-938. https://doi.org/10.1044/2017 AJSLP-16-0191

[5] Wang, Z., Liu, X. and Zhang, S. (2019) A New Decision Method for Public Opinion Crisis with the Intervention of Risk Perception of the Public. Complexity, 2019, Article ID: 9527218. https://doi.org/10.1155/2019/9527218

[6] Luo, X., Luo, L., Liu, H., Xiao, Y., Yu, X., Hou, X., Zeng, H., Zhang, F., Zhang, Y. and Zhao, Y. (2019) Needs Survey of Food Safety Intervention through We-Media: A Cross-Sectional Survey among Junior Educational and Medical University Students in Chongqing, China. Annals of Nutrition and Metabolism, 75, 218-219. https://doi.org/10.2196/preprints.17305

[7] Li, D., Zhang, Y. and Li, C. (2019) Mining Public Opinion on Transportation Systems Based on Social Media Data. Sustainability, 11, 4016. https://doi.org/10.3390/su11154016

[8] Wang, G., Wang, Y., Liu, Y. and Chi, Y. (2018) An Overview of Structurally Complex Network-Based Modeling of Public Opinion in the "We the Media" Era. International Journal of Modern Physics B, 32, Article ID: 1830006. https://doi.org/10.1142/S0217979218300062

[9] Soni, A. (2018) Out of Sight, Out of Mind? Investigating the Longitudinal Impact of the Fukushima Nuclear Accident on Public Opinion in the United States. Energy Policy, 122, 169-175. https://doi.org/10.1016/j.enpol.2018.07.024

[10] Alonso González, M. (2016) Opinión pública y web 2.0. Las redes digitalizan el barómetro político en España Spain. Revista Mexicana de Opinión Pública, 21, 95-113. https://doi.org/10.1016/j.rmop.2016.07.004

[11] Simpfendorfer, C.A., Heupel, M.R., White, W.T. and Dulvy, N.K. (2011) The Importance of Research and Public Opinion to Conservation Management of Sharks and Rays: A Synthesis. Marine and Freshwater Research, 62, 518-527. https://doi.org/10.1071/MF11086

[12] Feng, Z. (2019) Hot News Mining and Public Opinion Guidance Analysis Based on Sentiment Computing in Network Social Media. Personal and Ubiquitous Computing, 23, 373-381. https://doi.org/10.1007/s00779-018-01192-y

[13] Hamilton, L.C., Hartter, J. and Bell, E. (2019) Generation Gaps in US Public Opinion on Renewable Energy and Climate Change. PLOS ONE, 14, e0217608. https://doi.org/10.1371/journal.pone.0217608

[14] Asmolov, A.G. and Asmolov, G.A. (2009) From We-Media to I-Media: Transformation of Identity in the Virtual World. Voprosy Psikhologii, 3, 3-15. 
[15] Goldman, R.H., Kaser, D.J., Missmer, S.A., Farland, L.V., Scout, Ashby, R.K. and Ginsburg, E.S. (2017) Fertility Treatment for the Transgender Community: A Public Opinion Study. Journal of Assisted Reproduction and Genetics, 34, 1457-1467. https://doi.org/10.1007/s10815-017-1035-y

[16] DaVeiga, S.P. and Reddel, H. (2019) "Everybody's Got Asthma"-When Misunderstanding and Public Opinion Become Obstacles to the Care of Patients with Severe Asthma. Journal of Allergy and Clinical Immunology. In Practice, 7, 2622-2623. https://doi.org/10.1016/j.jaip.2019.06.002

[17] Ahmed, R., Bashir, A., Brown, J.E.P., Cox, J.A.G., Hilton, A.C., Hilton, C.E., Lambert, P.A., Theodosiou, E., Tritter, J.Q., Watkin, S.J. and Worthington, T. (2019) The Drugs Don't Work: Evaluation of Educational Theatre to Gauge and Influence Public Opinion on Antimicrobial Resistance. The Journal of Hospital Infection. https://doi.org/10.1016/j.jhin.2019.10.011

[18] O’Doherty, K.C. (2017) Deliberative Public Opinion: Development of a Social Construct. History of the Human Sciences, 30, 124-145. https://doi.org/10.1177/0952695117722718

[19] Gómez Vilchis, R.R. (2018) Confianza en el Congreso y opinión pública: El caso mexicano. Revista Mexicana de Ciencias Políticas y Sociales, 63, 117-139. https://doi.org/10.22201/fcpys.2448492xe.2018.233.59483

[20] Ituassu, A., Lifschitz, S., Capone, L., Vaz, M.B. and Mannheimer, V. (2018) Compartilhamento de mídia e preferência eleitoral no Twitter: Uma análise de opinião pública durante as eleições de 2014 no Brasil opinión pública durante las elecciones del año 2014 en Brasil Opinion during the 2014 Elections in Brazil. Palabra Clave, 21, 860-884. https://doi.org/10.5294/pacla.2018.21.3.9

[21] Pallin, R., Charbonneau, A., Wintemute, G.J. and Kravitz-Wirtz, N. (2019) California Public Opinion on Health Professionals Talking with Patients about Firearms. Health Affairs, 38, 1744-1751. https://doi.org/10.1377/hlthaff.2019.00602

[22] Parris, K.R., Harman, J.L., Jurbergs, N., Allen, J.M. and Canavera, K.E. (2019) Beyond Clinical Practice in Pediatric Psychology: Illustrative Experiences in Influencing Practice Changes, Public Opinion, and Governmental Policies. Psychological Services. https://doi.org/10.1037/ser0000385

[23] Kazyak, E. and Stange, M. (2018) Backlash or a Positive Response? Public Opinion of LGB Issues after Obergefell v. Hodges. Journal of Homosexuality, 65, 2028-2052. https://doi.org/10.1080/00918369.2017.1423216 